\title{
Pollutants resulting from intensive poultry farming activities and their impact on the environment
}

\author{
Roxana Mitroi ${ }^{1, *}$, Oana Stoian $^{1}$, Cristina Ileana Covaliu ${ }^{1}$, and Dragoş Manea ${ }^{2}$ \\ ${ }^{1}$ University Politehnica of Bucharest, Faculty of Biotechnical Systems Engineering, 313 Splaiul \\ Independenței, 060042, sector 6, Bucharest, Romania \\ ${ }^{2}$ INMA Bucharest, 6 Ion Ionescu de la Brad Bld, sect. 1, Bucharest, Romania
}

\begin{abstract}
Poultry farming activities can have a negative impact on the environment, namely: acidification (with $\mathrm{NH}_{3}$ mainly, $\mathrm{H}_{2} \mathrm{~S}, \mathrm{NO}_{\mathrm{x}}$ etc.); pollution of surface water and groundwater (with $\mathrm{NO}_{3}^{-}$and $\mathrm{NH}_{4}^{+}$); eutrophication $(\mathrm{N}, \mathrm{P})$; air pollution with $\mathrm{NH}_{3}, \mathrm{~N}_{2} \mathrm{O}$, NO, dust $\left(\mathrm{PM}_{10}\right.$ and $\left.\mathrm{PM}_{2.5}\right)$, bioaerosols; increasing the greenhouse effect $\left(\mathrm{CO}_{2}, \mathrm{CH}_{4}, \mathrm{~N}_{2} \mathrm{O}\right.$ etc); drying (use of groundwater); smells, noise; pollution with heavy metals, pesticides and toxic substances; the spread of pathogens that are resistant to antibiotics; pollution of waters with residues of pharmaceutical products. As a result, in order to prevent or reduce the negative impact on the environment, in the production process it is necessary to use BREF/BAT techniques (Best Available Techniques). The activity of poultry farming must be done according to the best available techniques: the farming system, production halls and related facilities are designed and built according to the latest standards in the field; implicitly the consumption of raw materials, waste emissions, wastewater, air pollutants values being according to the legislation [1].
\end{abstract}

\section{Introduction}

Bird shelters are zootechnical constructions intended for poultry or laying hens raising and exploiting. These constructions are designed according to the intended production (meat or eggs) and some aspects must be considered such as the technological solution related to the maintenance systems, the feeding system, watering, manure evacuation, the mechanization and automation degree of the production processes [2].

Projects aimed at intensive poultry farming activities are subject to an environmental impact assessment and this is due to the fact that poultry farming facilities involve a very large number of environmental impacts [3].

Regarding to the poultry farming activity, the potential impact on environmental factors refers to ammonia emissions to air, nitrogen and phosphorus leaks from manure into the soil, groundwater and surface water.

Poultry manure can be used as an organic fertilizer for plants, it has a high content of essential nutrients $[4,5]$, but improper management and excessive application of poultry manure lead to ammonia volatilization, nutrients leaching, higher nitrogen mineralization, damage of sensitive crops or surface water contamination by excessive phosphorus $[5,6$, 7]. 


\section{Impact on environmental factors}

The environmental impact assessment process aims to ensure the proper assessment of potential negative effects on the environment, the identification of alternatives, the establishment of measures to reduce and / or prevent negative effects on the environment.

The environmental impact evaluation process assesses feasible alternatives to the same project and makes recommendations for preventing, minimizing or mitigating adverse effects.

Assessing the impact of activities related to the intensive rearing of birds on environmental factors aims to determine the correct forms of impact.

In order to be able to establish measures to reduce or eliminate the negative impact of activities aimed at the intensive farming of birds on the environment, it is very important to know all the risk factors from the outset [3].

The impact forms involve the analysis of some key aspects that are presented in Table 1.

Table 1. Key aspects necessary to establish the impact forms on the environment [3]

\begin{tabular}{|l|l|}
\hline $\begin{array}{l}\text { The } \\
\text { characteristics } \\
\text { and duration } \\
\text { impact }\end{array}$ & $\begin{array}{l}\text { Determining the environmental aspects that may be affected. } \\
\text { Positive, neutral or negative nature of the impact. } \\
\text { Highlighting the forms of significant impact (positive and negative). } \\
\text { Description of impact (for example cumulative, continuous, intermittent, } \\
\text { occasional, temporary, short, medium or long term, direct/indirect, } \\
\text { reversible/irreversible). }\end{array}$ \\
\hline $\begin{array}{l}\text { Duration, scope } \\
\text { and complexity }\end{array}$ & $\begin{array}{l}\text { Quantification of the quantity or intensity with which the character / quality of } \\
\text { any aspect of the environment will change. } \\
\text { Indication of the geographical extent of the effects (if some, a large part or all of } \\
\text { the areas will be affected). } \\
\text { Description of the change degree (imperceptible, slight, observable or } \\
\text { significant). }\end{array}$ \\
\hline Consequences & $\begin{array}{l}\text { Indication of whether the impact can be avoided, mitigated or remedied. } \\
\text { Highlighting the forms of reversible impact. } \\
\text { Indication of whether a form of compensation is available, possible or acceptable. }\end{array}$ \\
\hline
\end{tabular}

The impact on the environment will be lower as the poultry farming plant is more modern and efficient. For this reason, it is recommended that, when assessing the impact on the environment, to take into account the age of the farm, in order to adopt appropriate measures, such as air filtration techniques, equipping the farm with technologies that allow reducing emissions as much as possible, changing manure transfer methods, imposing specific conditions regarding the manure storage [8].

\subsection{Impact on environmental factors}

In the case of an intensive poultry farming activity, potential cumulative effects should be considered, as presented in the following subchapters.

\subsubsection{Surface water quality}

By presenting measures to prevent/reduce/compensate the impact of the zootechnical farm and the available evidence it must demonstrate that the zootechnical activity will not significantly affect the water quality $[9,10]$. 


\subsubsection{Groundwater quality}

The groundwater can be affected by rainwater infiltration or manure that changes the quality of the groundwater, especially with regard to the nitrogen content $[9,10]$.

This potential effect should be considered in the context of the existence of other potential sources of groundwater damage [9].

\subsubsection{Metabolic gas emissions}

Poultry farms are a source of metabolic gas emissions (ammonia, methane). The analysis of the effects on air quality must be done taking into account the existence of other emission sources in the vicinity $[9,10]$.

\subsubsection{Potential impact on soil quality}

Animal manure contains nutrients and trace elements, which can be accumulated in the soil. Indirect impacts on the soil can also be represented by the destruction of ecosystems, the erosion of biodiversity by expanding the production of fodder crops in natural habitats or the overexploitation of non-renewable resources for fodder production [11].

\section{The main types of pollution generated by activities aimed at intensive poultry farming}

\subsection{Air pollution}

Air emissions from poultry farms are shown in Table 2.

Table 2. Air emissions associated with intensive poultry farms [12]

\begin{tabular}{|c|c|}
\hline Air & Production system \\
\hline Ammonia $\left(\mathrm{NH}_{3}\right)$ & Shelter for poultry, storage of manure \\
\hline Methane $\left(\mathrm{CH}_{4}\right)$ & Shelter for poultry, storage of manure \\
\hline Nitrogen oxide $\left(\mathrm{N}_{2} \mathrm{O}\right)$ & Shelter for poultry, storage of manure \\
\hline $\mathrm{NO}_{\mathrm{x}}$ & Indoor heating installations \\
\hline Carbon dioxide $\left(\mathrm{CO}_{2}\right)$ & $\begin{array}{c}\text { Shelter for poultry, fuel used for heating and transport, burning of } \\
\text { vegetable waste }\end{array}$ \\
\hline Scents $\left(\mathrm{H}_{2} \mathrm{~S}\right)$ & Shelter for poultry, storage and manure spreading \\
\hline Dust & $\begin{array}{c}\text { Food preparation, food storage, production halls, storage and } \\
\text { spreading of manure }\end{array}$ \\
\hline Smoke/CO & Burning of vegetable waste \\
\hline
\end{tabular}

From an environmental point of view, manure is the most important residue from farms activity. The measures applied to reduce emissions, associated with the collection, storage and manure treatment affect the structure and composition of manure and, finally, influence the emissions associated with the application of manure on agricultural lands. Associated with the storage of manure in the halls, $\mathrm{N}_{2} \mathrm{O}, \mathrm{CH}_{4}$ and, in small quantities, $\mathrm{H}_{2} \mathrm{~S}$ are released. The ammonium concentration can have high values, up to $40 \mathrm{ppm}$ in the halls where poultry are farmed and the concentrations of $\mathrm{N}_{2} \mathrm{O}$ and $\mathrm{CH}_{4}$ are slightly higher than in ambient air. Dust concentrations reach values of $10 \mathrm{mg} / \mathrm{m}^{3}$ in these intensive poultry farms (from 210 $\mathrm{mg} / \mathrm{m}^{3}$ for non-respirable particles and between $0.3-1,2 \mathrm{mg} / \mathrm{m}^{3}$ for respirable particles) [12]. 


\subsection{Water pollution}

Domestic wastewater from the sanitary filter drains into the internal sewer then will be collected in a concrete basin, from where it will be sent to the wastewater treatment plant.

The technological wastewater from the washing and rinsing of the poultry farming halls will be collected and directed to the concrete basin, then it will be sent to the wastewater treatment plant.

Given the variation of wastewater flow over time, their composition during the process of poultry farming on permanent bedding and the nature of pollutants, wastewater treatment can be achieved biologically.

Technological wastewater is not an important source of emissions from poultry farming activity, as it has a discontinuous regime and can be collected and treated. This wastewater will be treated in the treatment plant.

The disinfection of the poultry halls is done when they are empty, by spraying disinfectant solutions. Pollutants emitted into surface water associated with intensive poultry farms are presented in Table 3 .

Table 3. Pollutants emitted into surface water associated with intensive poultry farms

\begin{tabular}{|c|c|}
\hline Wastewater source & Emitted pollutants \\
\hline Washing the halls & $\begin{array}{c}\text { organic substances } \\
\text { suspended matter } \\
\text { detergents }\end{array}$ \\
\hline Hygienic - sanitary needs of the staff & $\begin{array}{c}\text { organic substances } \\
\text { suspended matter } \\
\text { detergents }\end{array}$ \\
\hline Rainwater collected from the platforms & suspended matter \\
\hline
\end{tabular}

Wastewater discharged directly into surface water can come from a variety of sources, but only emissions from manure treatment systems are normally allowed. Emissions from these sources contain $\mathrm{N}$ and $\mathrm{P}$, but an increase in CBO levels may also occur; especially in wastewater collected from farmyards and manure collection areas. However, of all the sources, field scattering is the activity responsible for the emissions of many compounds into air, soil, groundwater and surface water. Although manure treatment techniques are available, their application in the field is still the most widely used technique. Manure can be a good fertilizer, but where it is applied in excess of the capacity of the soil and the need for crops it becomes a major source of emissions [13].

Water pollution with nitrates, pathogenic phosphates (usually fecal germs and Salmonella) or heavy metals is the main cause for concern in the case of poultry farming.

\subsection{Soil pollution}

After the commissioning of the objective, a source of soil pollution could be the storage of manure, following the activity resulting in a relatively large amount of nitrogen and phosphorus. Pollution sources of nitrogen and phosphorus are presented in Table 4. Manure contains variable amounts of these nutrients as well as a number of minerals and essential elements: sulfur, magnesium, etc. 
Table 4. Sources of nitrogen and phosphorus pollution [12]

\begin{tabular}{|c|c|}
\hline Pollutant & Pollution sources \\
\hline Nitrogen & $\begin{array}{c}\text { accidental leaks of washing water } \\
\text { processes for denitrification of compounds with nitrogen }\left(\mathrm{NO}_{2}, \mathrm{NO}, \mathrm{N}_{2}\right) \\
\text { washing with rainwater of the soil on which the manure was spread } \\
\text { nitrogen and phosphorus accumulation in the organic component of the soil }\end{array}$ \\
\hline Phosphorus & $\begin{array}{c}\text { accidental leaks of washing water } \\
\text { washing with rainwater of the soil on which the manure was spread } \\
\text { nitrogen and phosphorus accumulation in the organic component of the soil }\end{array}$ \\
\hline
\end{tabular}

\subsection{Noise pollution}

Zootechnical activities can generate noise pollution due to:

- Fans in the production halls;

- Vehicles, pumping stations, etc.

The maximum admissible limits, based on which the state of the environment from an acoustic point of view in the area of such an objective is assessed, outdoors, are specified in the STAS 10009-88 Norm. In the case of buildings, the noise level limit must not exceed the maximum value of $50 \mathrm{~dB}$ (A) for the noise level outside the building, measured at a distance of 3 meters from it according to STAS 6161/189 [14].

\section{Conclusions}

This article presents and describes the impact of pollutants resulting from poultry farming on the environment. This study also shows the need to prevent, minimize or mitigate the negative effects produced by poultry farms. Pollutants from this industry can be mainly ammonia and methane, causing pollution of air, nitrogen and phosphorus from manure, causing pollution of soil, groundwater and surface water.

In conclusion, pollutants from poultry farming must be identified, and their concentration must be minimized by modernizing and streamlining the poultry plant. The endowment of the farm with technologies should be considered both for reducing emissions and for the correct transfer and storage of manure.

Potential benefits for farmers and environment can be obtained by using manure as fertilizer. Instead of facing an environmental problem, poultry manure can be a sustainable source of nutrients and energy.

In order to reduce the impact of pollutants on the environment, technologies have been developed, but one of the problems of their application in farms is the cost.

\section{References}

1. Directive 2010/75 / EU of the European Parliament and of the Council for the intensive rearing of poultry and pigs.

2. L. C. Stafie, R. Antohe, Laying hens in free range system PRACTICAL GROWING GUIDE, Waldpress Publishing House, Timisoara (2018)

3. I. Punga; coord .: I. R. Iordanov Environmental impact assessment: Case study /; AO "EcoContac". - Chisinau: S. n. (2016)

4. Y. Hu, H. Cheng, S. Tao, Environ. International, 107, 111-130 (2017) 
5. "Guide on facilities for the intensive rearing of farm animals, including poultry, laying birds, pigs and sows", developed within the Project "Development of guidelines for improving the administrative capacity of environmental protection authorities for the purpose of the unitary assessment procedure of environmental impact (EGEIA) ", SIPOCA code 19 - contracting authority: Ministry of Environment

6. Decision no. 964/2000 on the approval of the Action Plan for the protection of waters against nitrate pollution from agricultural sources with subsequent amendments and completions.

7. Government Decision no. $321 / 2005$ on the assessment and management of ambient noise, republished, with subsequent amendments and completions.

8. O. Dikinya, N. Mufwanzala, J. Soil Sci. Environ. Manage, 1(3), 46-54 (2010)

9. G.. Ren, T. Lin, Y. Ying, G.. Chowdhary, K. C.Ting, Computers and Electronics in Agriculture, 169, 105216 (2020)

10. Law no. $292 / 2018$ on assessing the impact of certain public and private projects on the environment.

11. P. Gerber, C. Opio, H. Steinfeld, Animal Production and Health Division, Food and Agriculture Organization of the United Nations, (2008)

12. J. Muhammad, S. Khan, M. Lei et al., Environ.Tech. \& Innovation, 19,100909 (2020)

13. K.Y. Chan, C. G. Dorahy, S. Tyler, A. T. Wells, P. P. Milham, I. Barchia, Soil Res. 45(2), 139-146 (2007)

14. K. C. Reddy, S. S. Reddy, R. K. Malik, J. L. Lemunyon, D. W. Reeves, Agro. J. 100(4), 1047-1055 (2008) 